
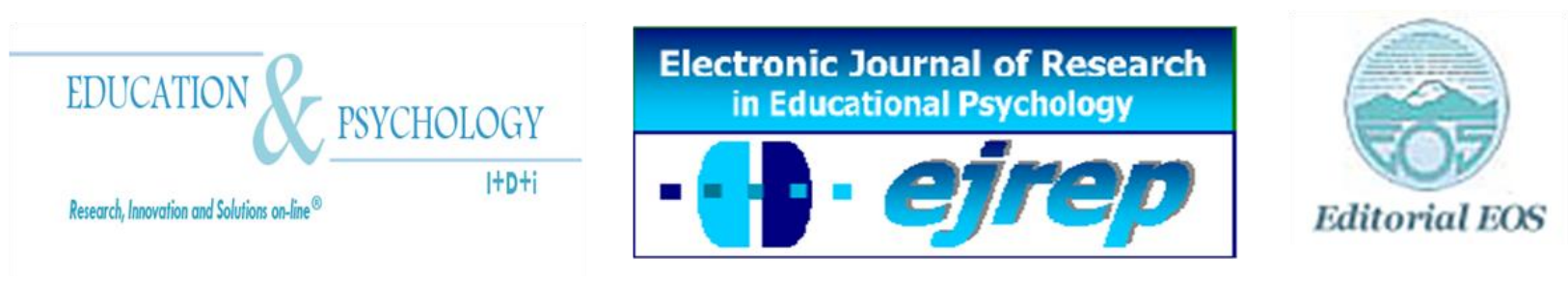

\title{
Effect of teaching of self-regulated learning strategies on attribution styles in students
}

\section{Jahanshir Tavakolizadeh $^{1}$, Soghra Ebrahimi Qavam ${ }^{2}$}

${ }^{1} \mathrm{PhD}$ in Educational Psychology, assistant profesor, Department of Public Health, School of Health and Social Development \& Health Promotion Research Center, Gonabad University of Medical Sciences, Gonabad, Khorasan Razavi.Iran.

${ }^{2} \mathrm{PhD}$ in Psychology, Associate professor, School of Psychology, Allame Tabatabayi University, Tehran.Iran

Iran

Correspondence: Jahanshir Tavakolizadeh,.Department of Public Health, School of Health and Social Development \& Health Promotion Research Center, Gonabad University of Medical Sciences, Gonabad, Khorasan Razavi, Iran. P.O. Box: 397. E-mail: drtavakolizadeh@gmail.com

(C) Education \& Psychology I+D+i and Editorial EOS (Spain) 


\begin{abstract}
Introduction. Nowadays, self-regulated learning has become an important focus in research and a large number of studies have been undergone about self-regulation, school achievement and motivation of learning, but few researches has been done in the field of self-regulated leaning and motivational variables and attributions. This research has been undergone with the general objective of proving the effectuality of teaching of self-regulated learning strategies on attribution styles in students.

Method. At this experimental study, the sample size consisted of 30 students, 15 each in experimental and control groups, and a random cluster multiple-stage sampling method was used on $2^{\text {nd }}$ grade junior-high boy students of the Heptagonal-zones of the Education Office in the city of Mashhad. At first, MSLQ and attribution styles in children questionnaires were executed as a pre-test in both groups. After which, only the experimental group was given teaching in self-regulated learning strategies for 18 one-hour sessions. After the teaching a post-test using the aforementioned questionnaires were taken from both groups. The data gathered were analyzed using SPSS software program and the independent T-test- differences between means.
\end{abstract}

Results. The results showed that there was a meaningful difference between means of attribution styles to negative events, internal attribution dimension for positive events in experimental and control groups; thus, training of self-regulated learning strategies produced a decrease in pessimistic attribution styles, and an increase in internal attribution dimension in the students.

Discussion and Conclusion. According to the results, teaching of self-regulated learning strategies have a significant effect on modification of attributions especially negative attributions. The modification of pessimistic attribution styles has an basic important on mental health. Thus, as an promotive mental health strategies recommend to teach self regulated learning strategies for students at schools

Keywords: self-regulated strategies, attribution styles, students

Received: 08/24/11 Initial acceptance: 15/09/11 Final acceptance: 11/07/11 


\section{El efecto de enseñar estrategias de aprendizaje autorregu- lado sobre estilos de atribución de los alumnos}

\section{Resumen}

Introducción. Hoy en día, la autoregulación del aprendizaje se ha convertido en un importante foco de investigación y un gran número de estudios se han centrado en la autorregulación, el rendimiento escolar y la motivación de aprender, pero pocas investigaciones se han hecho en el campo de la autorregulado, apoyadas en variables atribuciones. Esta investigación se ha realizado con el objetivo general de probar el mefctode la enseñanza del aprendizaje autorregulado y estrategias en los estilos de atribución de los estudiantes.

Método. En este estudio experimental, el tamaño de la muestra estuvo constituida por 30 estudiantes, 15 por cada uno de los grupos experimental y control, y un grupo aleatorio de múltiples etapas método de muestreo se utilizó en el segundo grado chico de secundaria de las zonas heptagonal de la Oficina de Educación, en la ciudad de Mashhad. En un primer momento, se aplicó, como un pre-test, los cuestionarios de los estilos de (MSLQ), en ambos grupos. Después de ello, sólo el grupo experimental recibió la enseñanza en estrategias de aprendizaje autorregulado durante 18 sesiones de una hora. Después de la enseñanza, se utilizó un post-test, con los cuestionarios antes mencionados, en losdos grupos. Los datos recogidos fueron analizados mediante el programa SPSS software y se realizaron diferencias de T-test independiente de entre los valores medios.

Resultados. Los resultados mostraron que hubo una diferencia significativa entre las medias de los estilos de atribuciónción a los acontecimientos negativos, la dimensión atribución interna de los acontecimientos positivos en los grupos experimental y control.Por lo tanto, la formación de estrategias de aprendizaje autorregulado produjo una disminución en los estilos de atribución pesimista, y un aumento de la dimensión atribución interna en los estudiantes. Discusión y Conclusiones. De acuerdo con los resultados, la enseñanza de estrategias de aprendizaje autorregulado teiene un efecto significativo en la modificación de las atribuciones especialmente en las atribuciones negativas. La modificación de los estilos de atribución pesimista tiene una importancia fundamental en la salud mental. Por lo tanto, para la promoción de las estrategias de salud mental, se recomienda para enseñar estrategias de aprendizaje autorregulado para los estudiantes en las escuelas.

Palabras clave: estrategias de autorregulación, los estilos de atribución, los estudiantes. 


\section{Introduction}

There has been a drastic change in the concept of educational psychology in the last three decades, so much so that nowadays, self-regulated learning has become a major focus of research (Pintrich 2000, Reynolds and Miller 2003; were quoted by Torrano Montalvo \& Gonzalez Torres, 2004). Although the term 'self-regulation' is synonymized with words such as self-control, self-discipline and self-direction, various definitions exist for the same which have arisen from the different theoretical concepts existing on self-regulated learning. Selfregulated learning is defined as the capability of active participation in the learning process from the view point of meta-cognition, motivation and behavior (Zimmerman 1986, 1989).

Self-regulated learners have skills from the perspective of meta-cognitive knowledge and know how to direct their mental processes in the direction of achievement and personal goals. They embark on planning, self-inspection, self-controlling and self-evaluation in the different stages of their learning. From the standpoint of motivation, this kind of learning greatly helps in the development of suitable adaptive beliefs and views in the field of education, especially in things like, preference in doing school work, effort, perseverance etc., and results in the fact that the individual feels worthy, strong and independent. Further, these learners have the ability to select, establish and create efficient learning environments (Pintrich 2000, Schunk and Ertmer 2000, Wigfield 1994, as quoted by Walters 2003). Moreover, self-regulated learners have different cognitive strategies - like repetition and rehearsal and elaboration and organization - which they can easily use for better comprehension and improvement of memory in carrying out their school work (Alexander, Graham and Harris 1998, Weinstein and Mayer 1986, as quoted by Walters 2003).

There are different models for self-regulated learning. One of the models is the Pintrich model (2000), where four phases are identified, these include different regulatory processes: planning, self-monitorng, control and evaluation. Each of these phases in turn incorporates self-regulated processes linked to specific dimentions: cognitive, motivationa and affective, behavioral and contextual (Villach and Lianos, 2007). 
During the initial years of cognitive change in educational psychology, i.e. in the ' 70 s and ' 80 s, research was mainly focused on cognitive variables, such as, processing information, cognitive styles, learning strategies, prior knowledge and thinking processes. In the 1980s and 1990s, extensive research was done in the field of motivational variables - selfconcept, beliefs, attributions, aims, etc. On the whole, it can be said that a large number of studies in the field of educational psychology have been undergone to see how self-regulated learning can result inhigher levels of educational achievement in students and facilitate learning (Lin \& Chen1995, Pintrich 1999, Zimmerman \& Martinez-Pons 1986, 1980). Some researchers of educational psychology in the field of self-regulated learning, like, Boakaertz (1999) etc., stand united on this point that although much research has been done in recent years on self-regulated learning - esespecially on learning styles and the cognitive aspects of learning processes- less attention has been paid to the role of self-regulated learning as an intricate and strong construct in other themes, like motivation and emotional processes. In other words, most research has been limited to meta-cognitive control systems and little study has been done on other control systems, such as, motivational, action, emotional controls and other topics related to system of self and objective behavior (Rozendaal, Minneart and Boakaertz, 2005). Thus the present research is focused on the theory of self-regulated learning and motivational aspects like attribution styles, in order to promote further understanding of the theoretical dimensions of self-regulated learning. With regards to self-regulated learning, Shonkoff and Philips (2000) have defined self-regulation as thecapability of the child to gain a control over physical actions, emotional management and maintenance of attention and concentration; and they believe the development of self-regulation is the basis for early childhood growth and is visible in all aspects of behavior. Bandura (2005) also believes that selfregulation is correlated to a growth in health, and is of special importance in health control.

Attribution styles are distinguished in the way an individual habitually conceptualizes the cause of events (Gross 2006 quotes Peterson \& Seligman). According to Cheng \& Furnham (2001), in the last two decades ample evidence has been accrued to show the direct relationship between attribution styles and mental health such as depression (Anderson, Sanjuan and Palomares, 1998), anxiety and depression (Dykema, and et al,1995 and Johnson and Miller,1990), self esteem (Romney, 1994) and shameness (Alfano, and et al, 1994). The studies show depressive patients emerge internal, global, and stable attributions for negative events. Although, paranoid patients show this attribution for positive events (Candido, 1990). 
Recent research in the field of self-regulated learning has also emphasized the importance of the role of attributions as motivational variables of self-regulated learning. In a review research, Peterson (1990) concludes that negative attribution styles are related to lower grades, not seeking help, vague goals, weak usage of learning strategies and lower achievement expectations. Moreover, students can modify these attributes by becoming aware of them and getting guidance from experienced teachers for the same. Zimmerman 2000 believes that in the stage of self-reflection, self-regulated learners interpret attributes, usually positive ones, for judging themselves in the field of academic tasks. These individuals have the tendency to attribute failure to reformable factors and success to personal merit (Nokelainen et al 2007). Shahrara and Soleiman-nejhad's research (2001) shows that a meaningfully positive correlation exists between the self-regulation of students and their internal locus of control.

One of the effective approaches for modifying pessimistic attributes is through training. Self-regulated learning, that has become one of the axes of educational activities, is a popular subject in the field of the educational psychology. Research has shown that school students function increased after they had been taught self-regulated learning strategies (Butler 1998, Neilans \& Israel 1981, O’Malley 1987), and students who had been taught selfregulated learning strategies became more self-regulated (Travers \& Sheckley 2000). Considering the mentioned theoretical basis and the dependence of self- regulated learning on attribution, the present research has been undergone to answer this important question that can the teaching of self-regulated learning have an influence on the modification of attributions.

\section{Hypotheses:}

The present research has examined the following two hypotheses in order to answer this important question:

Hypothesis 1: Teaching self-regulated learning strategies influences attribution styles in $2^{\text {nd }}$ grade middle-school boys.

Hypothesis 2: Teaching self-regulated learning strategies influences the various dimensions of attribution styles (internal-external, stable-unstable, global-specific) in $2^{\text {nd }}$ grade middle-school boys differently in positive and negative situations. 


\section{Methods}

\section{Participants and Design}

This research is an experimental study with a experimental and control double group in a pre- and post-test research design. Out of a total volume of $60,800,2^{\text {nd }}$ grade state middle-school boys studying during the school year Sept. 2008 - Sept. 2009 in the Heptagonal Zones of the Education Office of the city of Mashhad, a experimental size consisting of 30 students were randomly chosen by cluster method and divided into experimental and control groups. The research was done in multiple stages on both morning and afternoon shifts of the $2^{\text {nd }}$ grade of a junior-high school in Sector 4 of the Heptagonal Zones of the Education Office of Mashhad city.

\section{Instruments}

The data was gathered via the Motivated Strategies for Learning Questionnaire (Pintrich \& De Groot 1990), and the Children's Attribution styles Questionnaire (Petersen \& Seligman 1984). The Pintrich \& De Groot self-regulated learning scale - 1990 revision - was used to measure the self-regulated learning strategies of samples, also. This scale consists of 47 Items arranged into two sections, Motivational Beliefs and Self-regulated Learning Strategies. Pintrich and De Groot (1990) have used factor analysis for inspection of validity of this questionnaire. The said researchers used this method for measuring Motivational Beliefs through three factors: self-efficacy, intrinsic value and test anxiety; and for measuring selfregulated learning through two factors: implementation of cognitive strategies, meta-cognitive strategies and management of effort. Reliability was tested using the Cronbach's alpha method for the sub-scales of self-efficacy, intrinsic evaluation, test anxiety, and usage of cognitive and self-regulatory strategies; alpha coefficients of which stood at $.89, .87, .75, .83$ and .74 , respectively.

Musavinejhad (1998) has determined the validity of this questionnaire using the content validity and factorial analysis method and has found three factors: low-level cognitive strategies, high-level cognitive strategies and meta-cognitive self-regulation. The reliability for the above factors was defined as alpha coefficients, $.98, .79$ and .84 , respectively. The reliability coefficient for the self-regulated learning questionnaire of the present study was defined as 0.82 using the Cronbach's alpha method. 
In order to evaluate attribution styles, the Children's Attribution styles Questionnaire was used. This questionnaire has been prepared by Petersen \& Seligman in 1984 for children between 8 to 13 years of age, and has two, positive and negative, situations. Each situation has 3 attribution dimensions - internal, stable and global The initial format of this questionnaire consisted of 48 Items, which were standardized and some culture-related Items were omitted, by Heibatollahi (1994), thus reducing it to 36. Each item of this questionnaire is made up of two choices, and of these 36 terms, 18 are satisfactory situations, and the other 18 are unsatisfactory ones. Each Item was an assumed situation with 2 possible solutions. Heibatollahi has achieved reliability for the total positive and negative situations of the questionnaire at 0.46 and 0.47 , respectively. We determined the Questionnaire reliability Coefficient of 0.43 (with Kuder-Richardson) in this research.

\section{Procedure}

The procedure of research was such that after random selection of two classes of $2^{\text {nd }}$ grade middle-school from morning and evening shifts, and in order to determine condition of self-regulated learning, and attribution styles, a pre-test was taken in groups - before educational intervention - using the questionnaires on self-regulated learning, children's and attribution styles. After this, the samples were placed under an educational program (directexplanatory method) in the field of self-regulated learning for 18 sessions of 1 hour each (twice a week) with using the Pintrich model, and at the end of the training, a post-test of selfregulated learning, and attribution styles was executed on both groups.

\section{Data analysis}

The accumulated data was analyzed using SPSS software. The statistics were defined in tables, means, graphs, as well as in inferred statistics, by using the Covariance analysis test at first; but since some of the covariates were not achieved, the independent $T$ test- differences between means was used.

\section{Results}

Table nos. 1 -5 show results achieved after inferred analyses of the data in relation with the research hypothesis. As per the results shown in table 1 , total value calculated for $\mathrm{T}$ is 6.72 in 28 degree freedom and is thus greater than $\mathrm{T}$ Table Value $(\mathrm{T}=2.04)$. Therefore, null 
hypothesis is disproved and we can conclude with $95 \%$ certainty that there is meaningful difference between differential means of self-regulated strategies in the experimental and control group. As per the results in table 2, total value calculated for $\mathrm{T}$ is 1.94 in 28 degree freedom and is thus smaller than $\mathrm{T}$ value considered in the table $(\mathrm{T}=2.04)$. Therefore, null hypothesis is proved and we can claim with $95 \%$ certainty that there is no meaningful difference means of positive- and negative-event attribution styles of the experimental and control group.

Table 1. Independent T-test, differences between means of self-regulated learning strategies in experimental and control groups

\begin{tabular}{lccccccc}
\hline Groups & $\mathrm{N}$ & $\mathrm{M}$ & $\mathrm{SD}$ & Std Error & $\mathrm{t}-$ Value & $\mathrm{df}$ & Assumed T \\
\hline Experimental & 15 & -25.80 & 17.97 & 4.64 & -6.72 & & \\
Control & 15 & 9.06 & 8.97 & 2.31 & & 28 & .0001 \\
& & & & & & & \\
\hline
\end{tabular}

Table 2. Independent $T$ test, differences between means of positive and negative attribution styles in experimental and control groups

\begin{tabular}{llllllll}
\hline Groups & $\mathrm{N}$ & Mean & $\mathrm{S} D$ & Std Error & $\mathrm{t}$-Value & $\mathrm{df}$ & Assumed T \\
\hline Experimental & 15 & 0.80 & 3.95 & 1.02 & & & \\
Control & 15 & -1.60 & 2.72 & 0.70 & 1.94 & 28 & 0.063 \\
\hline
\end{tabular}

As per the results in tables $3 \& 4$ on negative-event attribution styles, total value calculated for $\mathrm{T}$ is 2.08 in 28 degree freedom and is thus bigger than $\mathrm{T}$ value in table $(\mathrm{T}=2.04)$. So, we conclude with $95 \%$ certainty that there is a meaningful difference between means of negative-event attribution styles of the two groups. On the other hand, total value calculated for T in positive-event attribution styles is 0.023 in 28 degree freedom and is thus smaller than $\mathrm{T}$ value ( $\mathrm{T}=2.04$ ), null hypothesis is seen and we can conclude with 95\% certainty that there is no meaningful difference between means of positive-event attribution styles of the experimental and control group. Thus, the first hypothesis of the research is proven. Or in other words, training the students with self-regulated learning strategies affects negative-event attribution styles but shows no effect on positive-event attribution styles. 
Table 3. Independent T test, differences between means of positive-evens attribution styles in experimental and control groups.

\begin{tabular}{llcclccc}
\hline Groups & $\mathrm{N}$ & Mean & $\mathrm{SD}$ & Std Error & $\mathrm{t}-$ Value & $\mathrm{df}$ & Assumed T \\
\hline Experimental & 15 & -0.067 & 2.49 & 0.64 & & & \\
Control & 15 & -0.27 & 2.22 & 0.57 & 0.23 & 28 & 0.818 \\
\hline
\end{tabular}

Table 4. Independent T test, differences between means of negative-evens attribution styles in experimental and control groups

\begin{tabular}{lllllllc}
\hline Groups & $\mathrm{N}$ & Mean & $\mathrm{S} \mathrm{D}$ & Std Error & $\mathrm{t}-$ Value & $\mathrm{df}$ & Assumed T \\
\hline Experimental & 15 & 0.87 & 3.20 & 0.83 & & & \\
Control & 15 & -1.33 & 2.5 & 0.65 & 2.08 & 28 & 0.046 \\
\hline
\end{tabular}

In tables 5, the results of the independent T-tests show differences between means of internality, stability and globality dimensions of attribution styles in positive and negative events between experimental and control groups.

According to the results seen in the table 5, total value calculated for $\mathrm{T}$ in internal attribution dimension for positive-event is 2.7 in 28 degree freedom and is greater than $\mathrm{T}$ value considered $(\mathrm{T}=2.04)$. Thus, with $95 \%$ certainty, we can claim that there is a significant difference between means of internal attribution dimensions of positive events in the experimental and control group. On the other hand, because criterion value calculated for $\mathrm{T}$ in stable positive-event attribution dimension is 1.21 and global T, 0.911, and as T stands at 1.44 in internal, 1.05 in stable and 1.40 in global, attribution styles in negative events in a 28 degree freedom, it is thus smaller than $\mathrm{T}$ value $(\mathrm{T}=2.04)$. Therefore, null hypothesis is proved and we can conclude with $95 \%$ certainty that there is no meaningful difference between means of positive events and dimensions of internal attribution, and stable and negative attribution dimensions of the experimental and control group. Thus, the second hypothesis of this research has been proven, as the training in self-regulated learning strategies was affected on higher levels of internal attribution dimension for positive events, while on the other hand it did not show a meaningful effect on other dimensions of attribution. 
Table 5. Independent T test, differences between means of positive-different attribution dimensions in experimental and control groups

\begin{tabular}{|c|c|c|c|c|c|c|c|c|}
\hline dimension & Groups & $\mathrm{N}$ & Mean & SD & Std Error & t-Value & $\mathrm{df}$ & Assumed T \\
\hline \multirow[t]{2}{*}{ P. internal } & $\mathrm{E}$ & 15 & -0.80 & 1.01 & 0.26 & & & \\
\hline & $\mathrm{C}$ & 15 & 0.20 & 1.01 & 0.26 & -2.7 & 28 & 0.012 \\
\hline \multirow[t]{2}{*}{ N. internal } & $\mathrm{E}$ & 15 & 0.40 & 1.68 & 0.43 & & & \\
\hline & $\mathrm{C}$ & 15 & -0.40 & 1.35 & 0.35 & 1.44 & 28 & 0.162 \\
\hline \multirow[t]{2}{*}{ P. stable } & $\mathrm{E}$ & 15 & 0.40 & 1.96 & 0.50 & & & \\
\hline & $\mathrm{C}$ & 15 & -0.33 & 1.29 & 0.33 & 1.21 & 28 & 0.237 \\
\hline \multirow[t]{2}{*}{ N. stable } & $\mathrm{E}$ & 15 & 0.60 & 1.96 & 0.50 & & & \\
\hline & $\mathrm{C}$ & 15 & -0.67 & 1.49 & 0.38 & 1.05 & 28 & 0.302 \\
\hline \multirow[t]{2}{*}{ P. global } & $\mathrm{E}$ & 15 & 0.33 & 1.17 & 0.30 & & & \\
\hline & $\mathrm{C}$ & 15 & -0.13 & 1.60 & 0.41 & 0.911 & 28 & 0.370 \\
\hline \multirow[t]{2}{*}{ N. global } & $\mathrm{E}$ & 15 & -0.13 & 1.24 & 0.32 & & & \\
\hline & $\mathrm{C}$ & 15 & -0.87 & 1.60 & 0.41 & 1.40 & 28 & 0.172 \\
\hline
\end{tabular}

\section{Discussion and conclusions}

The findings of this study confirmed the first hypothesis of this research. The results related to the statistical analysis of this hypothesis can be found in table 2 . They show that training in self-regulated learning quite evidently lowered negative (pessimistic) attribution style in the experimental group compared to the control group. This reduction of pessimistic styles is in agreement with Zimmerman's view (2000) that the learner embarked on interpreting and reforming negative attributions while in the self-judgment stage of learning selfregulation (Nokelainen, et al, 2007). As per the results of Preston's research (1990), lower scores, not looking for help, vague goals, weak usage of learning strategies and lower expec- 
tations from actions are all related to negative attribution styles. Thus, by using the different self-regulated learning strategies, such as, choosing of goals, searching for help, and suitable cognitive and meta-cognitive strategies, students could develop their learning; and by comparison and evaluation of their actions in the self-judgment and self-reflection stages, they could set about reforming their attribution to an extent.

Moreover, the second hypothesis of the research was also confirmed. The result of table 3 shows that the education of self-regulated learning has a meaningful effect on the internal dimension of attribution of $2^{\text {nd }}$ grade junior-high boys in positive situations, but did not seem to affect other dimensions. Further, the result of a comparison of the mean between pretests and post-tests of attribution dimension showed that while the difference between means of the stability dimension for positive events increased, it decreased in the case of negative events - yet, this difference was not statistically meaningful. This finding is in coordination with the opinion of Zimmerman and Kitsantas (1997) that claims self-regulated learners show a tendency for attributing success to competency and failure into reformable and unstable causes. The present Findings also coordinate with Shahrara and Soleiman-nejhad's (2001) research on the grounds that a meaningfully positive correlation exists between the selfregulation of the students and their internal locus of control. It appears that the students have been able to further their academic achievement by gaining knowledge in self-regulated learning strategies; and by evaluating progress in the field of pre-determined goals, they have attributed success to internal causes and failure to unstable ones.

On the whole, considering the decrease in general attribution dimension for positive events, it can be concluded that they have not yet been able to generalize their successes. Overally, the finding of this research can be conclude that the direct teaching of self-regulated learning strategies with Pintrich model has decresed attribution style for negative situation and has increase the internal dimension of attribution for positive situations. It seems students have activated the processes of self-regulation including planning, selfmonitorng, control and evaluation after teaching. Probably, active learning in students has been affected on their school achievement and also attribution style. They have attributed their positive events to themselves and their negative events to unstable, specific and external factors. 


\section{Limitations}

Some limitations should be taken into account. The first of these refer to use of self -reported measures for for completion of tasks related to self-regulated strategies (e.g., the extent of assurance of the reports that the exercises were done completely), and the lack of usage of information sources of the parents on the subject matter. The second limitation is related to finding generalization. The research sample limitted to only 2 nd grade state middleschool boys in this study. Thirdly, at this research, the teaching of self regulated learning strategies carries directly on students. Probably, other methods can be affected on attribution styles differently.

\section{Further Research}

In order to make a more precise judgment regarding these two research variables, more research must be done by taking the above factors into consideration. For limitations in self-reporting procedures, It is recommended to carry more researches with other measures especially observational measures and data resourses of students' parents and teachers. Also, it whould be beneficial for further researches to concentrate on students in different school courses. Finally, more studies can be directed to determine effect of other teaching methods in self-regulated learning strategies based on self-reflection, cooperative learning and scaffolding. In fact, some authors like Toranno Montello and Gonzales Torres (2004) state that teaching models have now emphasized the importance of practice, self-reflection and scaffolding in self-regulated learning, and they believe that intervention must be based on natural environment and real tasks related to preferences and needs of the students, which in turn will give the students the opportunity to reveal what they have learnt in personal, educational and social situations. 


\section{References}

Bandura, A. (2005). The primacy of self-regulation in health promotion. Applied Psychology: an international review. 54(2), 245-254.

Candido, C.L., \& Romney, D.M. (1990). Attribution styles in paranoid vs. depressed patients, British Journal of Medical Psychology, 63, 355-363.

Cheng, H., \& Furnham, A. (2001). Attribution styles and Personality as Predictors of Happiness and Mental Health. Journal of Happiness Studies, 3, 307-327.

Gross. James J (2006) Handbook of Emotion Regulation. Guilford Press.

Lin, C. S., and Chen, B. L. (1995). A study is to investigate the relationship between junior high students' self-regulated learning factors and learning performance and the effects of self-regulated teaching strategy on reading comprehension. Journal of Educational Psychology, 28, 15-58.

Mousavinejad, A. (1998).The relationship between motivational believes and self regulated Learning strategies and school achievement in in $3^{\text {th }}$ grade middle-school students (pp.1-40). MA. Dissertation.Tehran: Allameh Tabatabaei University (Persian).

Nokelainen, P., Tirri, K., \& Merenti-Valimaki, H-1. (2007). Investigating the influence of Attribution Styles on the Development of Mathematical Talent. Giffted Child Quarterly, 51, 64-81.

Peterson, C., (1990). Explanatory style on the classroom and on the playing field. In S. Graham and V. Folkes (Eds.), Attribution theory: Applications to achievement, mental health, and interpersonal conflict, (pp. 53-75). Hillsdale, NJ: Lawrence Erlbaum.

Pintrich, P. R. (1999). The role of motivation in promoting and sustaining self-regulated learning. International Journal of Educational Research, 31, 459-470.

Pintrich, P.R., \& De Groot, E. (1990). Motivational and self-regulated components of classroom academic performance. Journal of Educational Psychology, 82, 33-40.

Rochera, M.J., \& Naranjo, M. (2007). Fostering self-regulated learning in an assessment situation. Electronic Journal of Researc in Educational Psychology, 5(3), 805-824.

Rozendaal, J.S., Minaert, A., and Boekaerts, M. (2005).The influence of teacher perceived administration of self-regulated learning on students' motivation and information. Learning and Instruction, 15, 141-160.

Shahrara, M., Solaimannegad, A. (2002). Relationship between locus of control, self-regulation and school achievement. Journal of psychology, 2, 34-56. 
Shonkoff, J., \& D. Phillips, Eds. (2000). from neurons to neighborhoods: The science of early childhood development. A report of the National Research Council. Washington, DC: National Academies Press.

Torrano Montalvo, F., Gonzalez Torres. (2003). Self-regulation learning current and future direction. Electronic Journal of Research in Educational Psychology, 2, 1-34.

Travers, N. L \& Sheckley, B.G. (2000). Changes in students' self regulation based on different teaching methodologies. Paper presented $4^{\text {th }}$ Association for Institutional Reasearch forum, in formation for the next 100 years. Cincinnati, Ohio: May 21- May 24.2000.

Wolters.C.A. (2003) Regulation of motivation: Evaluating an underemphasized aspect of selfregulated learning. Educational Psychologist, 38, 189-205.

Zimmerman, B. (1989). A social cognitive view of self-regulated learning. Journal of Educational. 81, 329-339.

Zimmerman, B.(1986). Becoming a self-regulated learner: which are the key sub processes? Contemporary Educational Psychology, 11, 307-313.

Zimmerman, B J., \& Martinez-Pons, M. (1986). Development of a structured interview for assessing students' use of self -regulated learning strategies. American Educational Research Journal, 23, 614-628.

Zimmerman, B J., \& Martinez-Pons, M. (1988). Construct Validation of a strategy model of student self-regulated learning. Journal of Educational Psychology, 80, 284-290. 
Tavakolizadeh J. et al.

[This page intentionally left blank] 